\section{COMPARATIVE LITERATURE: RECENT DEBATES ON AN IMAGINED DISCIPLINE ${ }^{1}$}

\section{Suradech Chotiudompant ${ }^{2}$}

\begin{abstract}
Comparative literature is always a problematic discipline. Scholars from different countries and times such as René Wellek, Charles Bernheimer, Susan Bassnett, Gayatri Chakravorty Spivak, and Djelal Kadir, have attempted to delimit its scope. The variety of definitions have led to ensuing problems of shifting methodologies and frameworks. If, in the early twentieth century, a scholar tended to interrogate and theorise how one distinguished comparative literature, world literature, and general literature from one another, towards the end of that century and potentially continuing well into the new millennium, the parameters surrounding disciplinary formation have significantly changed, leading to a shift in the set of questions. Should comparative literature be differentiated from the
\end{abstract}

\footnotetext{
${ }^{1}$ Part of this essay was presented at the Workshop on Literary Communities on 27 May 2004 at University College London. The author would specifically like to thank Professor Dr Susan Bassnett for an interview, Assistant Professor Dr Charturee Tingsabadh and an anonymous reader for their valuable comments, as well as Phrae Chittiphalangsri for procuring recently published essays that are quintessential to the revision of this essay.

${ }^{2}$ Lecturer, Department of Comparative Literature, Faculty of Arts, Chulalongkorn University
}

relatively recent disciplines of postcolonial studies and cultural studies? If so, what are its scope and defining qualities? These puzzling parameters are what this essay aims to explore, as it is high time we looked inward, thinking of the discipline itself as an imagined community whose terrain is constantly shifting. Following this line of argument, the essay intends to probe into the construction of the discipline and gauge its historical development.

\section{Introduction}

What is comparative literature? This question is often posed by scholars working in the discipline, anxiously attempting to define its boundaries. Recently, this sense of anxiety has loomed large. Charles Bernheimer, in his introduction to Comparative Literature in the Age of Multiculturalism, directly addresses the problem, arguing that the discipline is 'anxiogenic' (1993: 1), facing a battle of definition on both fronts: comparison and literature. W.J.T. Mitchell, for instance, questions what he terms 'comparatism', believing that such a method of finding similarity and difference somehow restrains the quest for knowledge. Mitchell argues that the methodology of comparatism can blind us to 'the position of the comparatist, the site of comparison, the prescribed terms of similarity and difference, and the possibility of other relations besides comparative ones - juxtaposition, incommensurability, discontinuity, radical heterogeneity' (Mitchell, 1996: 323). George Steiner, in his 1994 inaugural lecture at the University of Oxford, goes even further, claiming that: 
every act of the reception of significant form, in language, in art, in music, is comparative. Cognition is re-cognition, either in the high Platonic sense of a remembrance of prior truths, or in that of psychology. We seek to understand, to 'place' the object before us - the text, the painting, the sonata - by giving it the intelligible, informing context of previous and related experience (Steiner, 1997: 142).

While we cannot agree on whether comparison is an activity, a function, or simply a practice, the identity of literature is also under attack by academics practising cultural studies, perceiving literature as simply another signifying cultural discourse. French thinkers such as Louis Althusser (2001) and Michel Foucault $(1984,1996)$ no longer view literature positively as the repository of desirable values and good tastes, as liberal humanists did in the first half of the twentieth century. For Althusser and Foucault, literature has become a site of cultural exchange where meanings are created and negotiated in power relations. Like other cultural manifestations, e.g. television programmes, music videos, soap opera, and popular romances, literature and its production are closely tied to the politics of class, gender, and race (see also Bennett, 1990; Easthope, 1991; Milner, 1996).

Like Bernheimer, Susan Bassnett (1993: 1), a leading British comparatist, anxiously begins her introduction to the discipline by asking what comparative literature is, and attempts to define it as follows:
the simplest answer is that comparative literature involves the study of text across cultures, that it is interdisciplinary and that it is concerned with patterns of connection in literatures across both time and space.

As any given text may be argued to be locked in its spatio-temporal dimension, this definition of comparative literature is so loose that any study concerning two texts can be encompassed by it. Acknowledging this, Bassnett (1993: 11) argues that this broad, nebulous definition may be the reason why the discipline seems to be losing ground and eventually this might account for its death.

I aim to explore the journey of the discipline from its 'official' beginning in the nineteenth century to its current state. Two hundred years have gone by and comparative literature is still a problematic discipline, which both fascinates and abhors students and scholars alike. It needs to be stressed that this essay is intended to chart comparative literature not simply as a practice, but as a discipline. Should we define it as a practice, it is likely that everyone who practises literary study with at least two texts in hand can be grouped under the comparative label, thus broadening the scope of comparative literature to the extent that it can be argued to be allembracing and non-existent at the same time. According to Wlad Godzich (1988: 19), there are four basic constituant elements of a discipline: 
(1) a normative object of study; (2) a defined field within which this object obtains or is constituted;

(3) a determinate set of theories and methodological procedures that are applied to the object in the field [...]; (4) a set of individuals who are recognised and identify themselves as practitioners of the discipline and some of whom are engaged in, among other things, the training of those who will succeed them in this practice.

In this essay, the development of comparative literature will be discussed in relation to these four elements to show how, in its journey to map the changing conditions of current literary relations, the discipline needs to be in constant flux in order to testify to its relevance to the body of knowledge in the modern world.

\section{The Origins and Crises of Comparative Literature}

The first use of the term 'comparative literature' was in nineteenth-century France, even though an attempt at a comparative perspective on literary studies began as early as the eighteenth century. ${ }^{3}$ In 1816, two French editors

\footnotetext{
${ }^{3}$ René Wellek (1970: 2 ) claims that Thomas Warton, in the preface to the first volume of History of English Poetry (1774), announced that he would present 'a comparative survey of the poetry in other nations'.
}

published a series of anthologies from French, classical, and English literatures under the title Cours de littérature comparée. Abel-François Villemain further popularised this comparative tendency by publishing lectures that encompassed literary studies of various nations (see Wellek, 1970: 10). In the early days, the discipline was made possible thanks to the then general proclivity of comparison as a viable method of organising knowledge, and comparatists were inclined to focus on an analysis of common themes or literary movements in different nations and literatures with a view to constructing an international literary history. The success of such comparative works as Georges Cuvier's Anatomie comparée (1800) or Joseph Marie Degérando's Historie comparée des systémes de philosophie (1804) testified to the predominant trend, demonstrating its attempt to build bridges between different cultures and nations. Edward Said (1995: 117) argues that such comparatism would become 'the boast of nineteenth-century method'.

The origin of the discipline was therefore closely tied to the rise of nationalism, which made comparatism possible in the first place due to the strengthening of nationhood. Paradoxical as it seems, the discipline was in principle intended to debunk national boundaries by emphasising literature as a cross-national discourse, or, in Manfred Gsteiger's words, 'a conscious internationalism is possible only in opposition to a conscious nationalism' (quoted in Guillén, 1993: 26). Comparative literature, then, was construed as a noble activity, aiming to 
expose its practitioners to the universality of the human capacity for truth and beauty, channelled through the medium of literature. This is reflected in Goethe's definition of Weltliteratur, the idea which he first entertained in a review in $1790 .{ }^{4}$ For him, the chief goal of world literature is: "not that the nations shall think alike, but that they shall learn how to understand each other, and, if they do not care to love one another, at least they will learn to tolerate one another' (Goethe, 1973: 8). This belief in the ideal unity of humanity through a comparative study of literature reverberated at the dawn of the twentieth century in a manifesto by George Edward Woodbury, the first chaired US professor in comparative literature at Columbia:

The emergence and growth of the new study known as Comparative Literature are incidental to the coming of this larger world and the entrance of scholars upon its work: the study will run its course, and together with other converging elements goes to its goal in the unity of mankind found in the spiritual unities of science, art, and love (Woodbury, 1973: 211).

\footnotetext{
4 'Everywhere one hears and reads about the progress of the human race, about the further prospects for world and human relationships. However that may be on the whole, which it is not my office to investigate and more closely determine, I nevertheless would personally like to make my friends aware that I am convinced a universal world literature is in the process of being constituted, in which an honourable role is reserved for us Germans' (quoted in Pizer, 2000: 215).
}

In its early days, comparative literature enjoyed a serene disciplinary formulation, with a clear normative object of study, i.e. literature, a quasi-scientific method of comparatism, and an ideal goal of revealing the aesthetic universality of human values. With chairs established both in Europe and the US, the discipline achieved its fourth constitutive element.

It goes without saying that from the nineteenth century until shortly after the Second World War the centre of comparative literature was in France. According to Claudio Guillén (1993: 47), this period is termed 'French Hour' and it was distinguished in 'the studies [that] were based on national literatures - on their preeminence - and on the connections between them. Major emphasis was placed on phenomena of influence, transmission, communication, transit (passage), or the link between activities and works belonging to different national spheres'. One of the main supporters of this trend was Jean-Marie Carré, who defined comparative literature as the study of 'spiritual international relations, of the factual contacts (rapports de fait) which existed between Byron and Pushkin, Goethe and Carlyle, Sir Walter Scott and Vigny, between the works, the inspirations and even the lives of writers belonging to several literatures' (quoted in Wellek, 1953: 1).

However, this 'French Hour' did not last long. In 1958, René Wellek announced a crisis of comparative literature at the Second Congress of the International Comparative Literature Association at Chapel Hill, deploring the positivist method set out by Carré which focused on such factual aspects as textual borrowing 
and reception between nations. For Wellek (1959: 151), this obsession with facts was allied to the preoccupation of the discipline with externals, making it 'a mere subdiscipline investigating data about the foreign sources and reputations of writers'. 5

Such a methodological difference exposed comparatists to the problem of its fundamental definition. As the success of comparative literature as a discipline in its early days relied upon national boundaries, Wellek's attack on a literary study dependent upon crude national delineation can be interpreted as a fullblown assault. Wellek's own opinion was that literary scholarship should not be defined in relation to nationalism, factualism, or provincialism; he believed that one should simply study Literature as one did Philosophy and History (Wellek, 1959: 155-56). In this light, comparative literature, for Wellek, was valid in the sense that it transcended national boundaries and necessitated an international perspective; however, it was not regarded as viable if it entailed the factual study of literary traffics, borrowings, and influences between nations, which implied the rigid framework of romantic nationalism. For Guillén (1993: 60), Wellek's assault on

\footnotetext{
${ }^{5}$ This debate might have been one of the reasons why Henry H.H. Remak controversially set out to expand the scope of the discipline in 1961 to mean not only the study of literature beyond the extents of one's country, but also 'the study of the relationships between literature on the one hand and other areas of knowledge and belief, such as the arts [...], philosophy, history, the social sciences [...], the sciences, religion, etc.' (Remak, 1961: 3).
}

Carré's strictly positivist methodology should be seen as a gesture to promote solidarity that transgressed national boundaries after the Second World War, as it signalled a deeper humanism, a need to downplay nationalistic or patriotic tendencies whilst celebrating the unity of humanity through the totality of literature.

By suggesting such a seemingly depoliticised perspective of internationalism, Wellek alerts us to the problem surrounding the word 'comparative'. What do we mean by 'comparative'? Does it simply entail the juxtaposition of two literatures, or does it imply a loftier notion of internationalism, which downplays the idea of nationhood and instead highlights literary poetics and history as ways to evaluate literature? Wellek's argument brought the discipline's defining characteristics under close scrutiny, as nationhood, for him, ceased to be an efficient strategy to analyse literature. With Wellek's argument, Godzich's second constitutive element of the discipline was under attack. Nationhood no longer seemed to be a logical strategy for the discipline as it ceased to be an object of transgression.

\section{The Age of Theory}

However, the introduction of theory into the literary curriculum provided a brief respite for comparative literature, as theory became a central bond with which the discipline was held together. By theory I mean specifically structuralist and poststructuralist theories, influenced by the paradigm shift instigated by Ferdinand de Saussure's structural linguistics and made fashionable in the Anglo-American literary scenes during the 1970s and 1980s (see also Cunningham, 2005). Theory was 
a natural home turf for the discipline, partly because it was widely believed that theory was transnational and could thus be applied to any text, independent of whence it came. Douwe Fokkema (1982: 12), for instance, claimed that there should be a paradigmatic revision of comparative literature from the viewpoint of Roman Jakobson's linguistics. The literary text should be replaced by the 'literary communication-situation' and the method of comparatism should be redefined as the juxtaposition between the literary and the non-literary so as to provide 'a spectrum of social functions of literature, enriching our own views on the social justification of literature' (Fokkema, 1982: 18). Fokkema's elaboration on the relationship between comparative literature and theory can be seen as a dutiful response to Henry H.H. Remak's 'first assignment' of the discipline, which demanded that

[it] constitute the tangible demonstration or refutation of general tenets about the structure of literature through the comparative analysis or synthesis of specific authors, texts, genres, currents, movements, periods, belonging to two or more cultural and/or linguistic units, whether different nations or significantly different cultures within a nation. In this kind of slant, illustrations taken from various national literatures are intended to serve as typological specimens somewhat divorced from their spatial or temporal contexts. In brief,

\section{Comparative Literature must be the principal laboratory for any theory of literature (Remak, 1980: 436 , my italics). ${ }^{6}$}

This recourse to theory was also promoted in the 1975 Greene Report to the American Comparative Literature Association (ACLA), which claimed that 'as participants [in the discipline], we need[ed] to muster the theoretical sophistication, the methodological rigour, the peculiar awareness of historical complexities our special training affords us' (Greene and others, 1993: 36). In other words, theory became in this period an added obligation, which in its turn changed traditional conceptions of literature and literary communication.

However, theory was also the factor that helped hasten the discipline's second crisis. Deconstruction, for instance, led to the elimination of traditional literary values by its fervent argument against literary reference to the external world. For M.H. Abrams (1977), poststructuralist theory, especially the strain espoused by Jacques Derrida in his of Grammatology, downplayed the traditional humanist quality of literature as a conveyor of existential experience, but focused instead on the logocentrism of written discourse, which maintained self-reflexive signification and the

\footnotetext{
${ }^{6}$ The other four assignments include: (1) cause-and-effect studies, inductive syntheses of historical moments, genres, currents, trends, etc.; (2) intensive juxtaposition of two or more compositions or essays not necessarily strictly related; (3) international literary traffics; and (4) interdisciplinary studies (see also Remak, 1980: 436).
} 
detachment of literature from the real world. Joining hands with Abrams was Wellek, who strenuously argued for literary reference to the outside world:

I am no defender of the Realist dogma. I have advocated the view that Realism is only one possible style of literature and I have always recognised the fantastic, the Utopian, the grotesque, the symbolic, and many other modes of representing reality. But literature does represent reality, however distorted and transformed. It both projects a world of its own creation and tells us something about our world. The deconstructionist theory is a flight from reality, and from history. Paradoxically, it leads to a new, anti-aesthetic ivory tower, to a new linguistic isolationism (Wellek, 2005: 45).

Another attack against literature in its traditional sense can be found in Saussure's theory of semiology, which led to an analysis of literature as one signifying discourse. Saussure's theory has assisted the institutionalisation of cultural studies, in which literature is regarded as a cultural manifestation among many, whose literariness and privileged status needs to be downplayed. Literature as an isolated institution imbued with its own values becomes problematic. This led to another crisis of the discipline, since the first and second constitutive elements, i.e. a normative object of study and the field of study, became destabilised. In other words, if the first crisis centred around the word 'comparative', the second crisis, in the age of Theory, shifted to the word 'literature'.

In their report on the status of comparative literature, Bernheimer and other ACLA committee members (1993: 42) tried to pacify this rift between literature and other cultural discourses by suggesting that: 'literary phenomena are no longer the exclusive focus of our discipline. Rather, literary texts are now being approached as one discursive practice among many others in a complex, shifting, and often contradictory field of cultural production'. However, the statement was received with mixed feelings. Mary Louise Pratt, for instance, revelled in this all-inclusive gesture and its politics of de-fencing, advancing her own concept of comparative literature as a place where the renewal of intellectual activities in the study of literature and culture is accommodated. According to Pratt (1993: 62):
the big picture is of comparative literature as an especially hospitable space for the cultivation of multilingualism, polyglossia, the arts of cultural mediation, deep intercultural understanding, and genuinely global consciousness.

While Pratt celebrated this new turn of the discipline with excitement, such critics as Michael Riffaterre (1993) and Jonathan Culler (1993) preferred to keep their guard, stressing that literature should still be the main focus of the discipline, otherwise it would risk losing its ground 
in the tangled web of interdisciplinarity. Peter Brooks was an extreme supporter of this line of thought, strongly arguing that literature should remain the main axle, despite the appearance that 'the study of literature is an outmoded mandarin practice that had better catch up with the hip world of cultural studies' (1993: 99).

The predominance of theory also had another impact. It transpired that poststructuralist and postmodern theories were inherently exclusivist and Eurocentric; texts written in the First World could be explained by theory produced by white male academics living in the US or Western Europe. Some critics, therefore, argue for the irrelevance of theory, especially postmodern theory, to Third World writings and even the implicit exploitation of the Other by the theorists. bell hooks (1997: 343), for example, states that:

$$
\begin{aligned}
& \text { Radical postmodernist } \\
& \text { practice, most powerfully } \\
& \text { conceptualised as a 'politics } \\
& \text { of difference', should } \\
& \text { incorporate the voices of } \\
& \text { displaced, marginalised, } \\
& \text { exploited and oppressed } \\
& \text { black people. It is sadly } \\
& \text { ironic that the contemporary } \\
& \text { discourse which talks the } \\
& \text { most about heterogeneity, }
\end{aligned}
$$

\footnotetext{
${ }^{7}$ Culler (2006: 89) believes that cultural studies should be entrusted to such departments that practise national literatures, as culture and national identity should be analysed together. Comparative literature, on the other hand, should focus mainly on literature and practitioners can use theoretical gains from cultural studies to enhance their comparative literary studies.
}

\begin{abstract}
the decentred subject, declaring breakthroughs that allow recognition of otherness, still directs its critical voice primarily to a specialised audience that shares a common language rooted in the very master narratives it claims to challenge.
\end{abstract}

hooks's condemnation can be seen as symptomatic of theory's exclusivity. Theory, which was understood to be the home turf of comparative literature, was becoming increasingly isolated from and oblivious to current global affairs. Its irrelevance damaged the integrity of the discipline and led Bassnett to pronounce the death of comparative literature in 1993. For her, the European model of the discipline, relying heavily on the use of post-structuralist theory to analyse texts, avoided basic questions generated by postcolonial studies. According to Bassnett (1993: 41):

The time has come to recognise that we now have a post-European model of comparative literature, one that reconsiders key questions of cultural identity, literary canons, the political implications of cultural influence, periodisation and literary history $[\ldots]$. 


\section{From the Crises to the Revival of the Discipline}

It should be pointed out that there have been other crises that comparative literature has encountered and that these may have occurred in continuum rather than in isolation. I have, however, singled out only two because each represents an attack on a fundamental aspect of the discipline. While the first crisis was related to the discipline's methodology of comparatism, of its simplistic claim to study the literatures of two nations, of literary traffics, be they borrowing or reception, the second crisis was mainly associated with the term 'literature' and its debunking by recent theories. Literature was what held the discipline together during the first crisis. In theorising comparative literature, Wellek did not explicitly scrutinise the concept of literature; the problem, for him, lay in distinguishing comparative literature from world and general literature, since the methodology of comparatism no longer held the discipline together and the borderlines among these disciplines were porous (see Wellek and Warren, 1963: 4653). The delineation of the discipline in this phase was its international perspective, which implicitly depended upon its dialectic relationship with nationalism.

The second crisis focused mainly on the entity of literature. Post-structuralist and postmodern theory, as well as cultural studies, have challenged the privileged cultural position of literature. Nevertheless, despite the claims by these theorists, literature has never been so secure of its place in the discipline of comparative literature. Marjorie Perloff (1993: 184) claims that

\begin{abstract}
the discipline itself, it seems, is always changing. But - strange as it may seem - the constant that has remained in all these disciplinary debates is literature itself. Not any one literature, not a list of 'great works' that everyone must read across the board [...], but the literary in its various forms - the literary of different countries, different cultures, different nations [...].
\end{abstract}

What helped comparative literature survive this crisis was, paradoxically, post-colonial studies. The replacement of the European model with the post-colonial paradigm makes possible the comparative study of literature, which, as Bassnett claims, can be used to emphasise identity politics and literary poetics in a new global sense. The post-colonial paradigm accentuates what Spivak (2003: 73) names 'planetarity', a tendency towards accepting difference in the same, as opposed to globalisation which aims to impose the same on difference. In a way, the question of nationhood comes back, but not as an ideology to be transgressed in favour of the facile emphasis on overriding humanist values. Nationhood, in this new post-colonial paradigm of comparative literature, is different from what comparatists perceived at the inception of the discipline; it is rather regarded as a construct that requires an act of public imagining or what Eric Hobsbaum (1983) terms 'the invention of tradition', in which nationhood is part of the imagined tradition that necessitates the repeated performance of rituals and 
symbols which in turn creates an emotional tie for the public. In this postcolonial light, nationhood becomes a subject that comparative literature needs to interrogate, especially in its vital role in maintaining the life-force of literature and sometimes becoming a theme that literature challenges.

Wellek chose to sidestep the question of nationhood in favour of internationalism, the view which finds its allegiance in Guillén's notion of comparative literature as 'a certain tendency or branch of literary investigation that involves the systematic study of supranational assemblages' (Guillén, 1993: 3). The new paradigm, whilst supporting the international perspective, does not downplay the involvement of nationhood in literary construction but embraces the contextualisation of literary study to the extent that it is integral to comparative analyses. Such a politicisation of reading marks a significant shift from Wellek's internationalism, which neutralises the act of reading and takes for granted the deeply political issues of nationalism and nationhood. For a post-colonial comparatist, the criteria of poetics and historicism are closely related to the construction of the nation. The popularisation of the folktale in Germany, for example, was closely linked to its attempt to consolidate different Germanic tribes into a single nation. In Latin America, literature was considered to be a civilising force which could help construct a nation (see Bhabha, 1990). In other words, literature plays a significant role in the construction of nation states and it would be insufficient if one tried to detach literary study from the fundamental concept of nationhood. This idea finds its close ally in Benedict Anderson's notion of nations as 'imagined communities', emerging out of public consent and shared memories, through the use of various forms of print-language, one of which is of course literature (see Anderson, 1991: 6-7). In short, this post-colonial paradigm grounds the analysis in history and attempts to strike a balance between history and poetics, internationalism and nationalism, and collectivity and singularity.

If the two crises of comparative literature centre around Godzich's first two disciplinary constituents, i.e. the object and the field, the second crisis also influences the third constituent, i.e. its theories and methodological procedures. In relation to the discipline, one can perceive a swing from objectivity to politics and ethics in the latest turn of comparative literature. What was implicit in the European model of comparative literature was its tendency towards an objective portrayal of literary relations among nations; in the post-colonial paradigm this objectivity is put to the test and in its place is a politics of friendship, which knowingly underpins the methodological reformation of the discipline. Even though certain beliefs in universal humanist values held by comparatists in the nineteenth and early twentieth centuries may be regarded as myths (Bassnett, 1993:21), it is in the furthering of these myths that the politics of the new comparative literature thrives, enmeshed in a desire not to find a universality of values in global literary expression, but to understand the world through the difference and sameness in literature in order to make the world a better place where alterity in whatever form will eventually be accepted. Spivak (2003: 100) claims: 'I am not advocating 
the politicisation of the discipline. I am advocating a depoliticisation of the politics of hostility toward a politics of friendship to come, and thinking of the role of Comparative Literature in such a responsible effort'. It is also in this optimistic spirit that Virgil Nemoianu (2000: 54) perceives the revival of the discipline, as he calls for a return to studies of common themes in the ethical framework of fairness and balance, forming the defining questions that mark the discipline as follows: "how can we give a fair account of the considerable differences between the manner in which such form-giving is understood and practised by different groups of humans, past and present? And how do we prepare for future modes of form-giving in as far as we can speculate upon them?'

However, not all critics are as optimistic about the future of the discipline. Djelal Kadir voices concern over the current shift in comparative literature and considers its attempt to include Third World texts as merely a complacent gesture towards difference. Writing in the atmosphere of modern-day terrorism, Kadir (2006a) is worried that our optimistic belief in world literature may be exposed as an attempt to view the world from a safer, thereby inaccurate, distance, and that Spivak's belief in planetarity, in the acceptance of alterity, may not be possible because the influence of globalisation is so pervasive that it is firmly rooted in human geography. According to him:

[...] what Spivak overlooks is the belatedness of staking comparative literature's claim to a planet whose every inch is already platted on universal global positioning systems, whose interplanetary space is thoroughly weaponised, and whose planetarity, rather than 'undivided 'natural' space' is already naturalised into martial containment (2006a: 71).

Nevertheless, it is to the credit of the discipline that these ideas concerning globalisation and terrorism can be discussed without it losing its ground. Optimistically or not, scholars still treat the discipline as a relevant formal training in keeping with current global affairs. The constant shifting of the discipline's boundaries may be the reason why comparative literature, however problematic, is always yet relevant to the present-day debates on arts and multiculturalism.

It may also explain the regular crises faced by the discipline. According to Thomas Docherty (2006: 25), crises happen at significant turns when important choices need to be made, as the Greek etymology krinein suggests. Comparative literature, as a discipline often positioned at the borders and thus rendered more vulnerable to the impact of paradigm shifts or new ways of thinking, is more likely than other disciplines to be subjected to these critical moments. Yet, these moments have never clearly signalled a farewell; on the contrary, they provide the discipline with opportunities to reflect upon its own formation and to consider possible amendments. It is highly ironic that these critical moments that allow for disciplinary adjustments have become one of the key reasons why practitioners of comparative literature are more than likely 
to feel ill at ease when asked what their discipline means, what they actually 'compare'. However, it is this slippery nature that enables comparative literature to remain relevant to contemporary global affairs. In the same way, Bassnett (2006: 10) argues that:

the future of comparative
literature lies in jettisoning
attempts to define the object
of study in any prescriptive
way and in focusing instead
on the idea of literature,
understood in the broadest
possible sense, and in
recognising the inevitable
interconnectedness that
comes from literary
transfer.

It should be noted here that, when Bassnett and Spivak declared the death of the discipline in 1993 and 2003 respectively, their pronouncements were made with certain reservations. While Bassnett (1993: 47, my italics) claims that: 'Today, comparative literature in one sense is dead', Spivak attempts to build a new comparative literature out of the ruins of the European paradigm, responding to the demographic move of the forces of people. In other words, neither of the scholars categorically deny the existence of comparative literature; for them, the older, Eurocentric paradigm of the discipline is no longer seen as viable and its place is supplanted by a more adventurous, globally conscious paradigm, revised in light of post-colonial studies, cultural studies, and area studies. This is the reason why, at about the same time that Spivak claimed that the discipline was dead, David Damrosch (2003b) gave an ACLA presidential address claiming that the discipline has witnessed an unprecedented growth. No longer imprisoned by the traditional paradigm of analysing two European literatures, Damrosch has taken up a new postcolonial paradigm of comparative literature, which favours contextualisation and a global transfer of texts (see also Damrosch, 2003c).

Comparative literature in this light survives the second crisis due to its fuzzy boundaries, more or less the same factor that induced the crisis in the first place. Its luck has also risen with a new preoccupation with nationhood. Frowned upon by Wellek and other traditional comparatists in favour of internationalism, nationhood now comes back to haunt comparative literature. In an age of multiculturalism and terrorism, it provides comparative literature with a relevance it has never been given before. If its European beginnings were due to a vision of a unified literature in spite of different geographical terrains, its new reformation should address the same issues, such as unity and difference, but from a different perspective. It should interrogate the process of international literary recognition (see Shih, 2004) and analyse how it entails both cultural and economical politics. It should also pay attention to cultural translation and its subtleties (see Apter, 2006). New tools and ways of thinking about nationhood and identity politics (especially that related to race, class, and gender) make comparative literature a suitable platform for the debate on contemporary cultural traffics. This is the reason why Haun Saussy begins his latest report on the discipline by saying that it has won its battles (2006: 3). 
By scrutinising its ups and downs, one can discern that comparative literature is more than an imagined literary community; it is of course imagined as other disciplines are, but it is different in that, by attempting to adapt itself to, and keep up with, current developments in the real world, it flaunts and revels in its imagination and imaginedness. In the spirit of what Saussy calls 'metadisciplinarity' (2006: 23), comparative literature constantly revises its disciplinary foundation and adjusts itself to new changes, without fear of losing its identity.

\section{Whither Comparative Literature in Thailand?}

To analyse comparative literature in Thailand fully would require a booklength study. Here, I will limit my reflections to the national perspective on comparative literature as a discipline as related to the points made above. The practice of comparative literature may have emerged in Thailand long time ago, but its appearance as an imagined discipline did not take place until around 70 years ago, with its introduction into the Arts curriculum of Chulalongkorn University, primarily as coursework in the BA programme in the Department of Thai (Sitha Pinitpuwadol and Ruenruthai Sujjapan, 1981: 6; Sutha Sastri, 1982: 8). Even though the university has had its MA programme in comparative literature since 1973, it was not until 1998 that the Comparative Literature Department was established with its own faculty. ${ }^{8}$ The

8 This 'official' beginning of the discipline, however, should not blind us to the fact that comparative literature as a practice had its emergence of the Department of Comparative Literature in Thailand was closely allied to the so-called 'American School', following Remak's definition and scope (Sutha Sastri, 1982: 8), ${ }^{9}$ as its two lecturers, Sutha Sastri and Trisilpa Boonkhachorn, were trained as comparatists at the University of Michigan, Ann Arbor. The focus on both comparison between literary works and interdisciplinary juxtaposition between literature and other arts is reflected in the variety of thesis topics. These range from 'traditional' works that focus on transnational literary transfer such as the influence of Western drama in the theatrical works of King Rama VI (1977) to those that aim for interdisciplinarity such as the study of the relationship between literary and visual arts in Ramakien (1996). ${ }^{10}$

Thai comparative literature did not encounter the Western disciplinary crises, partly because in Thailand the nature of comparison and literature has never been seriously questioned. The crux of the discipline seems to be its differential quality from literary studies practised in other departments, such as Thai,

earlier origins in such departments as Thai and Western Languages. For example, Cholthira Satyawadhna's MA thesis, written under the aegis of the Department of Thai in 1970 , focuses on the application of Western literary theories to Thai literature.

${ }^{9}$ Guillén, understably, prefers to call this 'American Hour' and considers the disparity between the French and the American Hours as generational rather than spatial.

\footnotetext{
${ }^{10}$ For the complete list of thesis topics in Thai, see http://www.arts.chula.ac.th/ $\sim$ complit/ thesis/thesis_th/abstrall_th.htm
} 
English/American, Eastern and Western Languages, whose aims and scope of possible thesis topics are clearly defined in national terms. Similar to its counterparts in the West, comparative literature in Thailand prospers when other departments keep guard on what their students can or cannot do.

However, of more concern than the nature of the discipline is Thai students' inability to fully engage with texts written in languages other than English. Most students can use English proficiently, though their second foreign language is not advanced enough for deep literary analysis. This risks compromising their comparative studies, which, I would argue, need to be international in scope and translational in focus. Thai comparatists should be trained as broadminded scholars specialising not only in Thai literature but willing to look outward to analyse other literatures with a view to bringing into relief a complex network of literary relations, which should not be exclusively seen on positivistic terms. The knowledge of other foreign languages, in addition to English, is fundamental to the achievement of this project.

Comparative literary studies can be conducted via the study of English or Thai translations, but students should be aware of the limitations this imposes. If translated texts are used as primary sources, analysis should centre on thematics, the study of common themes and motifs. Thematics should not be regarded as inferior; it can reveal interesting resonances that belie the process of cultural translation. Comparative thematic studies should be encouraged, as they enable students to look beyond the horizon of their own culture to witness the disparity or similarity of common human experiences in distinct contextualisation. ${ }^{11}$ In addition, in light of what we have earlier discussed, students should analyse how texts are related to the construction of the nation, as certain feelings, such as liberation or suffering, are also deployed, consciously or otherwise, as a strategy to redefine nationhood and instigate nationalism. This so-called post-colonial move may benefit the discipline of comparative literature as one of its reinvented politics is to look into the myth of nationhood in its attempt to gauge cultural boundaries.

In this regard, the introduction of theory in the curriculum may provide an interesting edge, once the student is conversant with theoretical tools and able to tackle literary works in a new light. Readiness to make use of theory should also be characteristic of Thai comparatists, when other departments protect their territories and

\footnotetext{
${ }^{11}$ In this line of thought, we are moving into the realm of world literature, in which, it has traditionally been believed, only the best or the most culturally 'representative' are chosen. However, such a conventional idea should be rethought, as works can also be chosen in terms of their common themes and students, via studying them, are able to discuss how these works are chosen and how they culturally represent and translate the common theme in their context. Katie Trumpener (2006: 196) convincingly maintains that with careful thinking and preparation, world literature can yield valuable results, 'raising questions of foundational violence and the ethics of conflict, of the logics of feud, massacre, terror, and genocide as well as the quasi-theological role of literature in mediating ideological shifts and moments of historical crisis, enacting conversion and convergence'.
} 
prefer to focus mainly on the aesthetic or socio-political dimensions of literature (although these boundaries have recently seemed to be more flexible). In this light, theory, especially those ideas marked as belonging to cultural studies, such as discourse and ideology, necessitate a revision of the concept of literary reference. Literature no longer reflects the outside world with language acting as a plain sheet of glass; on the contrary, literature represents a prejudiced worldview and should be approached with caution, not with full reverence. In other words, theory helps us see the complex rapport between literature and the world and understand that there has never been a one-to-one relationship, but an active process of negotiation entailing power relations in the representation of the real, closely related to the issues of identity politics and cultural translation. One can no longer think of literature as a repository of ideas and use them straight off the shelf; rather, these ideas are mediated and represented through the writer's perspective. ${ }^{12}$

${ }^{12}$ Cultural Studies, therefore, is highly relevant and I believe that Thai comparatists should be equipped with its theoretical tools, even though I would not go so far as to suggest that comparatists focus solely on studying cultural manifestations in other forms, such as television, radio, and advertising. Cultural studies was introduced to Thailand by the Faculty of Communication Arts and it is logical that they pursue that line of academic practice. The Department of Comparative Literature in the Faculty of Arts, on the contrary, should still focus on literary comparison or at least comparisons between literature and other media but with an informed theoretical framework.
In this light, however, theory should be used with caution and should focus on the understanding of literary texts, not for its own sake. In addition, it should also be contextualised or at least perceived as a tool from the West, thus possessing its own specificities. Thai comparatists should then be aware of their marginal positions. In applying theory to local works, they should also engage in a critical dialogue with theory itself and scrutinise the limits of its validity. Chetana Nagavajara's attempt to formulate a home-grown theory (2003) is an encouraging gesture and may be considered a call for participation which has yet to receive fruitful, active responses. It is my belief that, should we find it too difficult to look for an original Thai theory in the age when we are swamped with variegated multi-cultural forces, it may perhaps make sense to start with existing tools, especially postcolonial theoretical moves which have been created from the similarly unequal balance between the West and the Rest, and then move on to formulate our own particular perspective.

Such a process of theoretical revision can be fruitfully employed in Thailand, where the West has never territorially colonised but where the process of cultural and economic colonisation is ongoing. Some contemporary Thai literary works, for example, expose us to these power relations between us and the West. I believe that more insightful readings can be generated if the reader is acquainted not only with literary works of other nations that portray a similar situation but also with theoretical works detailing the complexities of globalisation and its accompanying phenomena, i.e. capitalism, urbanism, or consumption, and how these 
shape our lives. Such knowledge is not begotten by sheer positivism or personal experience alone, but by a thorough (self-) training in contemporary post-colonial thoughts. It becomes, I would argue, one of the main tasks of Thai comparatists to be more adventurous and tread in other fields of knowledge in order that their textual readings are rendered more relevant and in line with contemporary global complexities. Even though Bassnett (2006: 6) has recently revoked her argument that comparative literature was in its death throes, one of her claims still stands: that in other parts of the world, such as in the Third World and the Far East, the discipline is expanding and developing 'where it is explicitly linked to questions of national culture and identity' (1993: 9). From this perspective, the future of the discipline in Thailand is promising, though not exclusively in the way that Bassnett has predicted. In a nutshell, Thai comparatists are not only expected to be well-versed in their own literature, but their viewpoint should be cast from a different angle, not promoting the apotheosis of the national identity, but placing such identity in the complex relations of Thai literature to other literatures or cultural forces on global terms through a theory-oriented outlook.

To conclude here sounds too good to be true and I need to emphasise that the view laid out here has been forged by a young comparatist whose training was mainly in the West. But there is also a rub in this logical unfolding. If comparative literature in Thailand participates with its international counterparts in bringing new, fresh perspectives on literary studies, it is also our burden to continue finding new edges as whatever we have found will not be labelled as 'comparative literature' when other departments will start to follow our trends, hence the constant need to redefine the discipline. I agree with Saussy when he argues that 'the successful propagation of traits from the comparative literature family has not been accompanied by mechanisms of identification and control (of 'branding', to use a term shared by cowboys and marketing specialists). We are universal and anonymous donors - in ethical terms, a glorious role to play, but a perilous one in the scramble for resources, honor, and institutional legitimacy that we experience every day in the shrinking domain of the university humanities faculty. What is the reason for this anonymity? How might our discipline get the recognition it deserves?' (2006: 4) Taking Saussy's cue, I argue that comparative literature in Thailand also needs to come to terms with the disparity between theory and practice; it also needs to carve its own identity niche that is resilient enough to move with contemporary cultural complexities, yet solid enough to be recognised as a distinct discipline in the humanities. Recognising that my observations are inherently partial, I therefore hope that other comparatists not only reflect on this paper but also respond to it - and that the debates surrounding the discipline will therefore continue with renewed vigor.

\section{References}

Abrams, M.H. 1977. The Deconstructive Angel. Critical Inquiry 3: 425-38.

Althusser, Louis. 2001. Ideology and Ideological State Apparatuses (Notes towards an Investigation) (1969). Translated by Ben Brewster. In Vincent B. Leitch and others (eds), The Norton 
Anthology of Theory and Criticism, pp. 1483-1508. New York: W. W Norton.

Anderson, Benedict. 1991. Imagined Communities: Reflections on the Origin and Spread of Nationalism. $2^{\text {nd }}$ ed. London and New York: Verso.

Apter, Emily. 2006. The Translation Zone: A New Comparative Literature. Princeton: Princeton University Press.

Bassnett, Susan. 1993. Comparative Literature: A Critical Introduction. Oxford: Blackwell.

Bassnett, Susan. 2006. Reflections on Comparative Literature in the Twenty-First Century. Comparative Critical Studies 3.12: 3-11.

Bennett, Tony. 1990. Outside Literature. London and New York: Routledge.

Bernheimer, Charles. 1993. Introduction: The Anxieties of Comparison. In Charles Bernheimer (ed), Comparative Literature in the Age of Multiculturalism, pp. 1-7. Baltimore: The John Hopkins University Press.

Bernheimer, Charles, and others. 1993. The Bernheimer Report. In Charles Bernheimer (ed), Comparative Literature in the Age of Multiculturalism, pp. 39-48. Baltimore: The John Hopkins University Press.
Bhabha, Homi K. (ed). 1990. Nation and Narration. London: Routledge.

Boonkhachorn, Trisilpa. 2006. Comparative Literature: Paradigm and Methodology. [In Thai].

Brooks, Peter. 1993. Must We Apologise? In Charles Bernheimer (ed), Comparative Literature in the Age of Multiculturalism, pp. 97-106. Baltimore: The John Hopkins University Press.

Carré, Jean-Marie. 1952. Une Preface à La Littérature comparée. Yearbook of Comparative and General Literature 1: 8-9.

Casanova, Pascale. 2004. The World Republic of Letters. Translated by M. B. DeBevoise. Cambridge, Massachusetts: Harvard University Press.

Cooppan, Vilashini. 2001. World Literature and Global Theory: Comparative Literature for the New Millennium. Symploke 9.1-2: 15-43.

Culler, Jonathan. 1993. Comparative Literature, at Last! In Charles Bernheimer (ed), Comparative Literature in the Age of Multiculturalism, pp. 117-21. Baltimore: The John Hopkins University Press.

Culler, Jonathan. 1995. Comparability. World Literature Today 69.2: 26870. 
Culler, Jonathan. 1997. Literary Theory: A Very Short Introduction. Oxford: Oxford University Press.

Culler, Jonathan. 2006a. Comparative Literature, at Last. In Haun Saussy (ed.), Comparative Literature in an Age of Globalisation, pp. 237-248. Baltimore: The Johns Hopkins University Press.

Culler, Jonathan. 2006b. Whither Comparative Literature? Comparative Critical Studies 3.12: 85-97.

Cunningham, Valentine. 2005. Theory, What Theory? In Daphne Patai and Will H. Corral (eds), Theory's Empire: An Anthology of Dissent, pp. 24-41. New York: Columbia University Press.

Damrosch, David. 2003a. Comparative Literature? PMLA 118.2: 326-30.

Damrosch, David. 2003b. The 2003 ACLA Presidential Address (The Road of Excess: Comparative Literature at a Double Crossroads). Comparative Literature 55: vii-xv.

Damrosch, David. 2003c. What Is World Literature? Princeton: Princeton University Press.

Damrosch, David. 2006. Rebirth of a Discipline: The Global Origins of Comparative Studies.

Comparative Critical Studies 3.12: 99-112.
Derrida, Jacques. 1976. Of Grammatology. Translated by Gayatri Chakravorty Spivak. Baltimore: The Johns Hopkins University Press.

Dimock, Wai Chee. 2001. Literature for the Planet. PMLA 116.1: 173-88.

Easthope, Antony. 1991. Literary into Cultural Studies. London and New York: Routledge.

Fokkema, Douwe. 1982. Comparative Literature and the New Paradigm. Canadian Review of Comparative Literature 9: 1-18.

Foucault, Michel. 1984. Truth and Power. In Paul Rabinow (ed), The Foucault Reader, pp. 51-75. New York: Pantheon Books.

Foucault, Michel. 1996. The Order of Discourse (1971). In Philip Rice and Patricia Waugh (eds), Modern Literary Theory: A Reader, pp. 239-51. $3^{\text {rd }}$ ed. London: Arnold.

Godzich, Wlad. 1988. Emergent Literature and the Field of Comparative Literature. In Clayton Koelb and Susan Noakes (eds), The Comparative Perspective on Literature: Approaches to Theory and Practice, pp. 18-36. Ithaca: Cornell University Press.

Goethe, Johann von W. 1973. Some Passages Pertaining to the Concept of World Literature. In Hans-Joachim Schulz and Philip Rheim (eds), Comparative Literature: The Early Years, pp. 
3-11. Chapel Hill: University of North Carolina Press.

Greene, Thomas, and others. 1993. The Greene Report, 1975. In Charles Bernheimer (ed), Comparative Literature in the Age of Multiculturalism, pp.28-38. Baltimore: The John Hopkins University Press.

Guillén, Claudio. 1993. The Challenge of Comparative Literature. Translated by Cola Franzen. Cambridge, Massachusetts: Harvard University Press.

Hobsbaum, Eric, and Terence Ranger, eds. 1983. The Invention of Tradition. Cambridge: Cambridge University Press.

hooks, bell. 1996. Postmodern Blackness (1991). In Philip Rice and Patricia Waugh (eds), Modern Literary Theory: A Reader, pp. 341-48. $3^{\text {rd }}$ ed. London: Arnold.

Kadir, Djelal. 2001. Comparative Literature, the Transnational, and the Global. Neohelicon 28: 25-29.

Kadir, Djelal. 2004. To World, to Globalise - Comparative Literature's Crossroads. Comparative Literature Studies 41.1: 1-9.

Kadir, Djelal. 2006a. Comparative Literature in an Age of Terrorism. In Haun Saussy (ed.), Comparative Literature in an Age of Globalisation, pp. 68-77. Baltimore: The Johns Hopkins University Press.
Kadir, Djelal. 2006b. Comparative Literature in a World Become Tlön. Comparative Critical Studies 3.1-2: 125-38.

Lefevere, André. 1995. Comparative Literature and Translation. Comparative Literature 47.1: 110.

Levin, Harry, and others. 1993. The Levin Report, 1965. In Charles Bernheimer (ed), Comparative Literature in the Age of Multiculturalism, pp.21-27. Baltimore: The John Hopkins University Press.

Milner, Andrew. 1996. Literature, Culture and Society. London: UCL Press.

Mitchell, W. J. T. 1996. Why Comparions Are Odious. World Literature Today 70.2: 321-24.

Moretti, Franco. 2000. Conjectures on World Literature. New Left Review 1: 54-68.

Nagavajara, Chetana. 1989. Trends in Comparative Literary Studies (1988). In his For the Survival of Humanities: Collected Essays 1982-1988, pp. 339-94. Bangkok: Chulalongkorn University Press. [In Thai].

Nagavajara, Chetana. 2003. An Approach to the Construction of Arts Theory of the Motherland (2002). In his The Mutual Illumination of the Arts, pp. 101-26. Bangkok: Kombang. [In Thai]. 
Nemoianu, Virgil. 2000. Comparative Literature as a Phoenix. Literary Research/ Recherche littéraire 17.33: 51-55.

Perloff, Marjorie. 1993. 'Literature' in the Expanded Field. In Charles Bernheimer (ed), Comparative Literature in the Age of Multiculturalism, pp. 175-86. Baltimore: The John Hopkins University Press.

Pinitpuwadol, Sitha, and Ruenruthai Sujjapan. 1981. Comparative Literature. $4^{\text {th }}$ ed. Bangkok: Ramkhamhaeng University Press. [In Thai].

Pizer, John. 2000. Goethe's 'World Literature': Paradigm and Contemporary Cultural Globalisation. Comparative Literature 52: 213-27.

Pratt, Mary Louise. 1993. Comparative Literature and Global Citizenship. In Charles Bernheimer (ed), Comparative Literature in the Age of Multiculturalism, pp. 58-65. Baltimore: The John Hopkins University Press.

Remak, Henry H.H. 1960. Comparative Literature at the Crossroads: Diagnosis, Therapy, and Prognosis. Yearbook of Comparative and General Literature 9: 1-28.

Remak, Henry H.H. 1961. Comparative Literature, Its Definition and Function. In Newton P. Stallknecht, and Horst Frenz (eds), Comparative Literature:
Method and Perspective, pp. 3-37. Carbondale: Southern Illinois University Press.

Remak, Henry H.H. 1980. The Future of Comparative Literature. In Béla Köpeczi and György M. Vajda (eds), Proceedings of the $8^{\text {th }}$ Congress of the International Comparative Literature Association, 2 vols, ii, pp. 429-87. Stuttgart: Kunst und Wissen \& Erich Bieber.

Riffaterre, Michael. 1993. On the Complementarity of Comparative Literature and Cultural Studies. In Charles Bernheimer (ed), Comparative Literature in the Age of Multiculturalism, pp. 66-73. Baltimore: The John Hopkins University Press.

Said, Edward. 1995. Orientalism. London: Penguin.

Said, Edward. 2001. Globalising Literary Study. PMLA 116.1: 64-68.

Sastri, Sutha. 1982. Comparative Literature. Bangkok: Thai Wattana Panich. [In Thai].

Satyawadhna, Cholthira. 1970. Application of Western Methods of Modern Literary Criticism to Thai Literature. Unpublished MA thesis, Department of Thai, Chulalongkorn University. [In Thai].

Saussy, Huan. 2003. Comparative Literature? PMLA 118.2: 336-41. 
Saussy, Huan. 2006. Exquisite Cadavers Stitched from Fresh Nightmares: Of Memes, Hives, and Selfish Genes. In Haun Saussy (ed.), Comparative Literature in an Age of Globalisation, pp. 3-42. Baltimore: The Johns Hopkins University Press.

Shih, Shu-mei. 2004. Global Literature and the Technologies of Recognition. PMLA 119.1: 16-30.

Spivak, Gayatri Chakravorty. 2003. Death of the Discipline. New York: Columbia University Press.

Steiner, George. 1997. What Is Comparative Literature? In his No Passion Spent: Essays 1978-1996. London: Faber and Faber.

Trumpener, Katie. 2006. World Music, World Literature: A Geopolitical View. In Haun Saussy (ed.), Comparative Literature in an Age of Globalisation, pp. 185-202.

Weisstein, Ulrich. 1973. Comparative Literature and Literary Theory: Survey and Introduction. Translated by William Riggan. Bloomington: Indiana University Press.

Wellek, René. 1953. The Concept of Comparative Literature. Yearbook of Comparative and General Literature 2: 1-5.

Wellek, René. 1959. The Crisis of Comparative Literature. In Werner P. Friedrich (ed), Proceedings of the Second Congress of the International
Comparative Literature

Association (2 vols), i, pp. 149-59. Chapel Hill: University of North Carolina Press.

Wellek, René, and Austin Warren. 1963. Theory of Literature. $3^{\text {rd }} \mathrm{ed}$. London: Peregrine.

Wellek, René. 1970. The Name and Nature of Comparative Literature. In his Discriminations: Further Concepts of Criticism, pp. 1-36. New Haven: Yale University Press.

Wellek, René. 2005. Destroying Literary Studies. In Daphne Patai and Will H. Corral (eds), Theory's Empire: An Anthology of Dissent, pp. 4151. New York: Columbia University Press.

Woodbury, George Edward. 1973. Editorial. In Hans-Joachim Schulz and Philip Rheim (eds), Comparative Literature: The Early Years, p. 211. Chapel Hill: University of North Carolina Press. 